\title{
Implementasi Model Pembelajaran Rekreasi-Prokreasi dalam Membaca Kritis Teks Eksplanasi di SMK
}

\author{
Bambang Eko Hari Cahyono ${ }^{\mathrm{a}, 1}$, Lulus Irawati ${ }^{\text {a,2 }}$, dan Devit Tri Candrawati ${ }^{\text {a,3 }}$ \\ aniversitas PGRI Madiun, Indonesia \\ I'behc.fpbs@gmail.com; ${ }^{1}$ lulusirawati@unipma.ac.id; ${ }^{3}$ devit.candrawati@gmail.com
}

Article info ABSTRACT

Article history:

Received: 24-08-2019

Revised : 28-09-2019

Accepted: 20-10-2019

Keywords: critical reading critical explanatory Implementation Ponorogo rekreasi-prokreasi
This study aims to describe and explain (1) the conditions of critical reading learning in SMK Negeri 1 Ponorogo students, (2) the implementation of recreation-procreative learning models in learning to read critical explanatory texts, and (3) the constraints faced by teachers and students. This descriptive qualitative research uses data sources in the form of informants, events, and documents. The selected informants were Indonesian Language teachers and class XI students. Data were collected in-depth interview techniques, observation techniques, and documentation studies. Validity through extending the participation of researchers, making observations diligently and carefully, and triangulating data sources. Data analysis was performed using an interactive analysis model. The results showed that: (1) critical reading learning has not been implemented well due to the low student interest in reading, and the inaccuracy of teachers in choosing learning methods, materials, and media, (2) learning to read critical explanatory texts with recreationalprocreation models can create an atmosphere new learning that is fun for students, encourages the growth and development of critical thinking skills, encourages students to express their opinions critically, and improves other language skills, (3) the obstacles faced by teachers and students, namely the lack of tools and learning media, students are less active, the teacher has not been able to become a facilitator of critical reading learning well, as well as the limited language skills of students.

Penelitian ini bertujuan untuk mendeskripsikan dan menjelaskan (1) kondisi pembelajaran membaca kritis pada siswa SMK Negeri 1 Ponorogo, (2) implementasi model pembelajaran rekreasiprokreasi dalam pembelajaran membaca kritis teks eksplanasi, dan (3) kendala-kendala yang dihadapi oleh guru dan siswa. Penelitian dengan metode deskriptif kualitatif ini menggunakan sumber data, berupa: informan, peristiwa, dan dokumen. Informan yang dipilih yaitu guru Bahasa Indonesia dan siswa kelas XI. Data dikumpulkan dengan teknik wawancara mendalam, teknik observasi, dan studi dokumentasi. Validitas melalui memperpanjang keikutsertaan peneliti, mengadakan pengamatan dengan tekun dan saksama, dan melakukan triangulasi sumber data. Analisis data dilakukan dengan model analisis interaktif. Hasil penelitian menunjukkan bahwa: (1) pembelajaran membaca kritis belum terlaksana dengan baik karena rendahnya minat baca siswa, dan kekurangtepatan guru dalam memilih metode, materi, dan media pembelajaran, (2) 
pembelajaran membaca kritis teks eksplanasi dengan model rekreasi-prokreasi mampu menciptakan suasana pembelajaran baru yang menyenangkan bagi siswa, mendorong tumbuh kembang kemampuan berpikir kritis, mendorong siswa berani mengemukakan pendapat secara kritis, dan meningkatkan kemampuan berbahasa lainnya, (3) kendala-kendala yang dihadapi guru dan siswa, yaitu kurang tersedianya alat dan media pembelajaran, siswa kurang aktif, guru belum mampu menjadi fasilitator pembelajaran membaca kritis secara baik, serta terbatasnya kemampuan berbahasa siswa.

Copyright ( 2019 Institut Agama Islam Negeri Syekh Nurjati Cirebon.

\section{PENDAHULUAN}

All rights reserved.

Membaca merupakan salah satu dari empat keterampilan berbahasa (Muhyidin, 2018). Pembaca yang dewasa adalah seorang pembaca yang bisa mengembangkan arti serta konsep-konsep baru dari bahan bacaan yang telah dibacanya. Biasanya, siswa SLTA digolongkan sebagai pembaca yang belum dewasa. Hal ini kebanyakan disebabkan mereka belum bisa mengembangkan masalah-masalah kompleks dan konsep-konsep abstrak yang dijumpainya. Dalam hal ini, guru harus dapat memberikan tuntunan serta bisa menentukan bahan bacaan yang sesuai dengan kecepatan membaca para siswanya.

Kegiatan membaca kritis cocok diterapkan pada pembelajaran bahasa Indonesia di tingkat SLTA. Kegiatan membaca dalam bahasa Indonesia menimbulkan pelbagai aspek postif dalam pembelajaran (Hudaa, 2018). Kegiatan membaca kritis dapat meningkatkan kepekaan berpikir kritis dalam diri siswa dengan cara melihat motif penulis kemudian menilainya, membaca secara analitis untuk menilai apakah yang dibacanya itu bermanfaat atau tidak, memiliki kelaikan atau tidak apabila disampaikan kepada orang lain baik secara lisan maupun tulisan (Dalman, 2014).

Kegiatan membaca kritis juga berkaitan dengan kemampuan berpikir kreatif, sebagai salah satu wujud kreativitas. Menurut McGregor (2007), berpikir kreatif merupakan berpikir yang mengarah pada pemerolehan wawasan baru, pendekatan baru, atau cara baru dalam memahami sesuatu. Menurut Livne (2008), kemampuan berpikir kreatif merujuk pada kemampuan untuk menghasilkan solusi bervariasi yang bersifat baru terhadap masalah yang bersifat terbuka, atau 

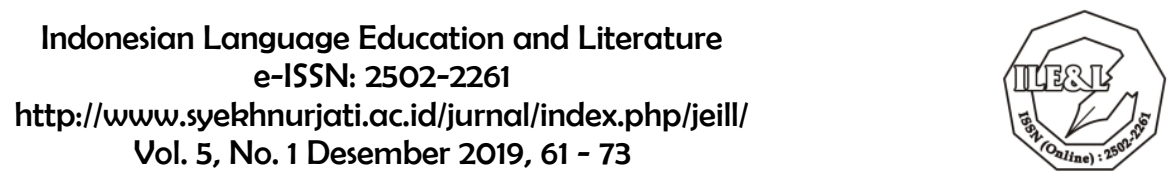

kemampuan untuk menghasilkan ide baru dalam menghasilkan suatu produk pemikiran.

Menurut Hayati, Atmazaki, dan Abdurrahman (2015), pentingnya pengajaran membaca kritis tidak hanya terlihat pada fungsi dan kegiatannya, tetapi juga pada tujuan yang ingin dicapai dari proses membaca tersebut. Proses membaca kritis melibatkan aspek berpikir seperti mengingat, memahami, membedakan, membandingkan, menemukan, menganalisis, mengorganisasi dan menerapkan hal-hal yang terdapat dalam bacaan. Pembaca kritis tidak hanya menyerap apa yang diungkapkan penulis, tetapi juga berpikir tentang masalah yang dibahas serta mampu menganalisis dan memberikan penilaian.

Dalam membaca kritis siswa sangat sensitif terhadap asumsi dan implikasi, mereka memahami serta merasakan warna kata-kata, bentuk frasa-frasa, dan bobot kalimat, bahkan mereka mungkin sangat memerhatikan tanda-tanda baca. Dengan kata lain, pada tahap membaca kritis ini siswa selain mampu memahami isi bacaan secara literal dan interpretatif, siswa juga mampu memahami isi bacaan secara kritis. Artinya, pembaca di sini dituntut untuk menganalisis atau menelaah secara mendalam dan mengevaluasi isi teks yang dibacanya. Dengan demikian, mereka pun menerapkan kemampuan berpikir kritis dan berpikir kreatif (Dalman, 2015).

Berdasarkan pengamatan peneliti, kegiatan membaca yang dilakukan siswa kelas XI SMKN 1 Ponorogo pada umumnya belum menerapkan membaca bacaan secara kritis seperti mengingat, memahami, membedakan, membandingkan, menemukan, menganalisis, mengorganisasi dan menerapkan hal-hal yang terkandung dalam bacaan. Siswa hanya menangkap apa yang tersurat dalam bacaan, siswa membaca hanya untuk menjawab pertanyaan yang diberikan guru mengenai bacaan tersebut. Jika guru bertanya tentang tanggapan siswa terhadap isi bacaan yang telah dibaca sebelumnya, sebagian siswa mengalami kesulitan dalam mengungkapkannya kembali.

Proses membaca yang dilakukan siswa hanya sebatas mengingat belum menerapkan proses membaca kritis. Hal ini, secara tidak langsung memberikan dampak terhadap proses pembelajaran khususnya belajar bahasa Indonesia. Oleh sebab itu, guru harus mampu menerapkan proses membaca kritis dengan 
menerapkan inovasi dalam pembelajaran, sehingga siswa lebih kritis dalam memahami, menganalisis, dan memberikan penilaian terhadap suatu permasalahan serta mengungkapkan kembali menurut pemahamannya melalui tulisan, sebagai hasil proses berpikir kreatif siswa.

Secara umum, karakteristik berpikir kritis dan kreatif tampak dalam proses berpikir saat siswa memecahkan masalah yang berhubungan dengan: (1) kelancaran dalam memberikan jawaban dan atau mengemukakan pendapat atau ide-ide; (2) kelenturan berupa kemampuan untuk mengemukakan berbagai alternatif dalam memecahkan masalah; (3) keaslian berupa kemampuan untuk menghasilkan berbagai ide atau karya yang asli hasil pemikiran sendiri; (4) elaborasi berupa kemampuan untuk memperluas ide dan aspek-aspek yang mungkin tidak terpikirkan atau terlihat oleh orang lain; dan (5) keuletan dan kesabaran dalam menghadapi suatu situasi yang tidak menentu (Jamaris, 2006). Suharman (1998) menambahkan bahwa berpikir kritis berkaitan dengan aktivitas berpikir. Berpikir kritis selalu melibatkan proses berpikir di dalam diri seseorang. Aktivitas ini merupakan suatu proses mental yang tidak tampak oleh orang lain, dan hanya dirasakan oleh orang yang bersangkutan. Aktivitas ini bersifat kompleks, karena melibatkan sejumlah kemampuan kognitif seperti persepsi, atensi, ingatan, imagery, penalaran, imajinasi, pengambilan keputusan, dan pemecahan masalah.

Menurut pengamatan peneliti, belum maksimalnya kemampuan membaca kritis para siswa salah satunya disebabkan oleh model pembelajaran yang dipergunakan oleh guru. Model pembelajaran yang dipilih guru masih bersifat tradisional, yaitu dengan mengandalkan penjelasan atau ceramah dari guru yang bersifat mekanis dan kurang memberi ruang kepada para siswa untuk berpikir kritis dan kreatif. Oleh sebab itu, dalam pembelajaran membaca kritis perlu dipilih model pembelajaran yang sejalan dengan pengembangan kemampuan berpikir kritis dan berpikir kreatif siswa, yaitu model pembelajaran rekreasi-prokreasi. Mengingat pembelajaran membaca kritis menekankan pada pengembangan berpikir kritis dan berpikir kreatif maka peneliti memandang bahwa model pembelajaran rekreasi-prokreasi ini juga cocok diterapkan dalam pembelajaran membaca kritis. 
Pembelajaran membaca kritis dengan model rekreasi-prokreasi berpijak pada teori Andragogi, yakni pendekatan pembelajaran yang memusatkan perhatiannya pada peserta didik. Inti teori Andragogi yang dikembangkan oleh Knowles (dalam Cahyono, 2017) adalah teknologi keterlibatan diri (ego) peserta didik. Artinya, bahwa kunci keberhasilan adalam proses pembelajaran terletak pada keterlibatan diri mereka dalam proses pembelajaran itu. Teori Andragogi memandang peserta didik sebagai orang dewasa yang mampu berpikir dan bependapat. Peserta didiklah yang aktif belajar dan berpikir, sedangkan guru berperan sebagai fasilitator, motivator, penggerak, pembimbing, dan/ atau pemandu. Jadi, Andragogi berkebalikan dengan pendekatan yang sering dilaksanakan selama ini yakni pendekatan Pedagogi yang lebih memusatkan pembelajaran pada figur guru.

Model pembelajaran rekreasi-prokreasi dalam pembelajaran membaca kritis dilakukan melalui dua kegiatan, yaitu kegiatan rekreasi dan prokreasi. Kegiatan pada tahap rekreasi menekankan pada aspek membaca secara cermat serta menemukan makna yang tersurat dan tersirat di dalam bacaan. Setelah kegiatan rekreasi selesai dilaksanakan, kegiatan selanjutnya adalah kegiatan prokreasi. Pembelajaran membaca kritis pada tingkat prokreasi dibedakan menjadi dua tingkatan, yaitu responsi dan produksi. Responsi berpijak pada pemahamannya atas bacaan yang dibacanya, siswa melalui analisis yang intensif berusaha memberikan tanggapan terhadap apa yang ditemukan dalam teks bacaan sesuai dengan wawasan dan horizon harapannya serta ketajaman intelektualnya. Pada tahap produksi siswa diharapkan dapat mengungkapkan penilaiannya secara tertulis terhadap motif penulis dan kemanfaatan teks yang dibacanya.

\section{METODE}

Penelitian ini dilaksanakan selama 6 bulan di SMKN 1 Ponorogo. Pendekatan penelitian yang dipergunakan yaitu pendekatan deskriptif kualitatif. Data berupa sejumlah informasi yang berkaitan dengan kondisi pembelajaran membaca kritis yang berlangsung di lokasi penelitian. Jenis sumber data yang dipergunakan dalam penelitian ini yaitu: (1) informan sebanyak 3 orang informan utama, yaitu 1 orang guru matapelajaran bahasa Indonesia dan 2 orang siswa kelas 


\section{Indonesian Language Education and Literature \\ e-ISSN: 2502-2261 \\ http://www.syekhnurjati.ac.id/jurnal/index.php/jeill/ \\ Vol. 5, No. 1 Desember 2019, 61 - 73}

XI, (2) peristiwa atau aktivitas kegiatan pembelajaran membaca kritis di dalam kelas, dan (3) dokumen atau arsip yang berupa kurikulum beserta perangkatperangkatnya, bahan ajar yang dipergunakan guru, tugas-tugas, data rekam jejak guru, dan dokumen-dokumen lain yang terkait. Data dikumpulkan melalui: (1) dokumentasi, (2) observasi berperan secara pasif, dan (3) wawancara mendalam. Analisis data dilakukan dengan model analisis interaktif (Miles \& Huberman, 1992; Sutopo, 2002; Faisal, 2003), yang dilaksanakan dalam dua tahap, yaitu pada saat atau selama berlangsungnya pengumpulan data dan setelah pengumpulan data. Analisis data dilakukan melalui 3 alur kegiatan yang berlangsung secara bersamaan, yaitu (1) reduksi data, (2) penyajian data, dan (3) penarikan simpulan/verifikasi. Teknik-teknik yang dipilih untuk mengecek keabsahan data dalam penelitian ini, yaitu dengan jalan: (1) memperpanjang keikutsertaan peneliti, (2) mengadakan pengamatan dengan tekun dan saksama, (3) melakukan triangulasi sumber data, dan (4) memeriksa hasil temuan melalui diskusi terpumpun (focus group discussion).

\section{HASIL DAN PEMBAHASAN}

Berdasarkan analisis data diperoleh hasil mengenai kondisi pembelajaran membaca kritis teks eksplanasi di tempat penelitian, yaitu bahwa pembelajaran membaca kritis belum terlaksana dengan baik di sekolah yang diteliti. Hal ini disebabkan oleh beberapa faktor, di antaranya yaitu aspek membaca kritis tidak berdiri sendiri sebagai sebuah KD, tetapi pembelajarannya hanya diintegrasikan ke dalam pembelajaran KD yang sudah ada. Rendahnya minat baca siswa juga menjadi faktor yang menghambat, sedangkan dari faktor guru ditemukan adanya kekurangtepatan guru dalam memilih metode, materi, dan media pembelajaran dalam pembelajaran membaca kritis.

Dalam Kurikulum 2013, pembelajaran bahasa Indonesia diorientasikan pada pembelajaran berbasis teks. Pembelajaran bahasa Indonesia berbasis teks memberi ruang kepada peserta didik untuk mengembangkan berbagai jenis struktur berpikir, karena setiap teks memiliki struktur berpikir yang berbeda satu sama lain. Semakin banyak teks yang dikuasai, maka semakin banyak struktur berpikir yang dikuasai peserta didik. Materi pembelajaran membaca kritis tidak diberikan 
dalam bentuk kompetensi dasar tersendiri tetapi diintegrasikan ke dalam pembelajaran berbagai macam teks.

Pengertian teks dalam Kurikulum 2013 ini berbeda dengan pengertian teks selama ini. Teks selama ini diartikan sebagai wacana tertulis. Dalam Kurikulum 2013, teks tidak diartikan sebagai bentuk bahasa tulis. Teks dimaknai sebagai satuan bahasa yang mengungkapkan makna secara kontekstual. Teks eksplanasi merupakan jenis teks baru yang ada pada pembelajaran Kurikulum 2013. Teks eksplanasi disusun dengan struktur yang meliputi pernyataan umum, deretan penjelas, dan interpretasi (opsional). Pembelajaran kompetensi dasar tentang teks eksplanasi ini sesuai diintegrasikan dengan pembelajaran membaca kritis dan bisa dikaji dan dianalisis dengan perpektif berpikir kritis.

Teks eksplanasi harus ditulis berdasarkan kaidah teks baku yang mencakup ejaan, tanda baca, pilihan kata, keefektifan kalimat, dan keterpaduan pendapat. Tujuan kebahasaan dari teks eksplanasi adalah untuk menerangkan proses-proses yang terjadi dalam pembentukan atau kegiatan yang terkait dengan fenomenafenomena alam, sosial, ilmu pengetahuan, budaya, dan lainnya yang bertujuan menjelaskan. Dapat dikatakan bahwa teks eksplanasi fokus pada hal umum (generic), bukan partisipan manusia (nonhuman participants), misalnya gempa bumi, banjir, hujan, dan pelangi. Selain itu, dimungkinkan menggunakan istilah ilmiah.

Meskipun tidak secara eksplisit tertulis sebagai kompetensi dasar di dalam kurikulum, pembelajaran membaca tetap dianggap penting karena membaca merupakan salah satu pembelajaran yang tidak hanya mengasah kemampuan dalam memahami pesan tulisan, akan tetapi melatih kemampuan berpikir siswa karena keterampilan ini mengolah dan mengasah informasi dari bacaan yang sedang dibaca dan menghubungkan bacaan dengan informasi terdahulu yang telah diperolehnya. Melalui kegiatan membaca, siswa dapat memahami ilmu pengetahuan dan mengikuti perkembangan ilmu pengetahuan. Menilik hal tersebut, kemampuan membaca merupakan kemampuan yang penting dan harus dimiliki oleh siswa untuk dapat bersaing dan mengikuti perkembangan zaman. Berkaitan dengan hal tersebut, dalam laporan PISA tahun 2015 disebutkan bahwa kemampuan membaca siswa Indonesia berada di urutan ke 62 dari 70 negara hasil 
survei PISA. Hal tersebut menunjukkan bahwa kemampuan berpikir siswa Indonesia melalui keterampilan membaca perlu mendapatkan perhatian. Dalam pembelajaran membaca, siswa diharapkan tidak hanya membaca bacaan secara sekilas, tetapi juga memahami isi bacaan secara keseluruhan. Memahami isi bacaan dapat dilakukan dengan membaca kritis.

Tujuan membaca kritis adalah untuk mencari fakta-fakta yang terdapat di buku atau bacaan tersebut, kemudian memberi penilaian terhadap fakta yang didapat. Membaca kritis berarti membaca dengan analisis dan dengan penilaian, jadi pembaca tidak boleh hanya menyerap masalah yang ada, tetapi juga berpikir bagaimana penyelesaiannya terhadap masalah tersebut. Keterampilan membaca kritis perlu mendapatkan perhatian, mengingat sistem pendidikan Indonesia saat ini menggunakan Kurikulum 2013 revisi yang menitikberatkan pembelajaran bahasa Indonesia pada teks. Keterampilan ini dapat membantu siswa untuk lebih memahami jenis teks, tujuan penulis, dan pesan tersirat yang dikemukakan oleh penulis.

Dengan membaca kritis pembaca akan dapat pula mencamkan lebih mendalam apa yang dibacanya, dan dia pun akan mempunyai kepercayaan diri yang lebih mantap daripada kalau dia membaca tanpa usaha berpikir secara kritis. Oleh karena itu, membaca kritis harus menjadi ciri semua kegiatan membaca yang bertujuan memahami isi bacaan yang sebaik-baiknya. Melihat pentingnya keterampilan membaca kritis dan melihat kompleksitas keterampilan membaca kritis, maka perlu pengembangan keterampilan membaca kritis secara lebih intensif. Secara tegas dinyatakan bahwa pengajaran membaca tidak boleh hanya difokuskan pada pemahaman pengetahuan faktual karena pada hakikatnya muara dari semua kegiatan membaca adalah membaca kritis (all reading is inevitably critical in nature). Oleh karena itu, disarankan keterampilan membaca kritis harus ditempatkan sebagai kurikulum inti di sekolah.

Pada dasarnya berpikir kritis (critical thinking) bertujuan untuk membentuk anak didik agar mampu berpikir netral, objektif, beralasan, logis, jelas dan tepat. Dengan tujuan tersebut, siswa dilatih untuk membuat keputusan yang bijak, dengan memberikan alasan mengenai kebenaran tentang nilai sebuah pernyataan; dan mengambil tindakan dalam sebuah kondisi. Melalui proses itu 
diharapkan dapat ditanamkan pada siswa kecenderungan berpikir kritis atau dispositions of critical thinking, yakni: (1) mencari kejelasan tesis atau masalah dan alasan serta alternatif; (2) ingin tahu dan menyebutkan sumber handal serta berpikiran terbuka; (3) melihat persoalan secara menyeluruh tanpa menyimpang dari inti persoalan; (4) mengambil dan mengubah sikap karena bukti dan alasan; dan (5) sadar akan perasaan, tingkat pengetahuan, dan derajat kecanggihan orang lain. Tingkat berpikir kritis memiliki pengaruh yang signifikan terhadap kemampuan membaca kritis.

Pembelajaran yang dilakukan mengolaborasi berbagai kemampuan peserta didik, mengaktivasi peserta didik, melibatkan konteks di sekitarnya, melibatkan kegiatan diskusi, dan lain-lain. Hal-hal yang harus diperhatikan dalam pembelajaran membaca kritis dan kreatif yaitu tentang pemilihan bahan wacana. Kemampuan kekritisan siswa dalam menganalisis suatu wacana tentu saja dimulai dari pemilihan bahan bacaan. Sebagai pendidik ketika akan memberikan tes wacana kemampuan pemahaman dan kekritisan suatu isi wacana, hendaknya dimulai dari pemilihan bacaan yang memiliki isi memancing siswa berpikir kritis.

Pembelajaran membaca kritis dengan model rekreasi-prokreasi berpijak pada teori Andragogi, yakni pendekatan pembelajaran yang memusatkan perhatiannya pada peserta didik (mahasiswa). Inti teori Andragogi yang dikembangkan oleh Knowles adalah teknologi keterlibatan diri (ego) peserta didik. Artinya, bahwa kunci keberhasilan adalam proses pembelajaran terletak pada keterlibatan diri mereka dalam pembelajaran itu. Teori Andragogi memandang peserta didik sebagai orang dewasa yang mampu berpikir secara kritis. Peserta didiklah yang aktif belajar dan berpikir, sedangkan guru berperan sebagai fasilitator, motivator, penggerak, pembimbing, dan/ atau pemandu.

Model pembelajaran rekreasi-prokreasi dalam pembelajaran membaca kritis dilakukan melalui dua kegiatan, yaitu kegiatan rekreasi dan prokreasi. Kegiatan rekreasi dilakukan melalui 2 tahap. Tahap pertama, yaitu tahap menaklukkan kata (word attack skills). Kegiatan yang dilakukan meliputi mengenali dan memberikan makna terhadap unit bahasa pada teks yang dibaca, mulai dari fonem, suku kata, dan kata. Selain itu, juga melakukan pemahaman isi bacaan, mengenali fakta-faktanya, memahami ide pokoknya, dan menginterpretasikan apa yang 

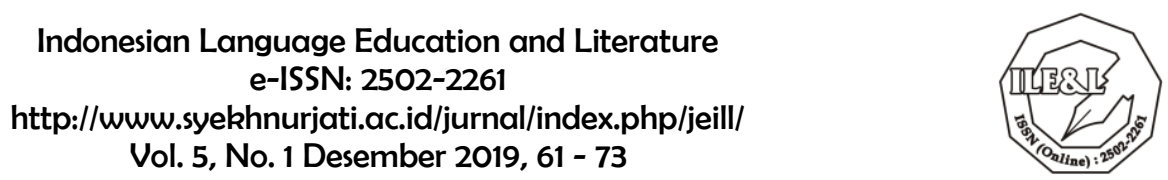

dibaca. Tahap kedua, tahap comprehension skills, yaitu pembaca kritis menggunakan kompetensinya mulai dari kompetensi linguistik, gramatikal, dan sosial untuk memberikan makna terhadap teks yang dibaca. Kegiatan lain yang dilakukan yaitu menguji sumber penulis. Apakah sumbernya dapat dipercaya? Apakah cukup akurat? Apakah penulis kompeten di bidangnya? Termasuk juga diuji pandangan dan tujuan serta asumsi yang tersirat dalam penulisan untuk membedakan bahan yang disajikan sebagai opini dan fakta.

Setelah kegiatan rekreasi selesai dilaksanakan, kegiatan selanjutnya adalah kegiatan prokreasi, atau merangsang siswa untuk berpikir kritis dan kreatif. Pembelajaran membaca kritis pada tingkat prokreasi dibedakan menjadi dua tingkatan, yaitu responsi dan produksi. Pada tahap responsi, masing-masing siswa memperoleh peluang sebebas-bebasnya untuk memberikan respon terhadap teks yang dibacanya. Respon tercermin dari sikap menerima atau menolak. Artinya, pembaca boleh percaya, curiga, mempertanyakan, atau tidak mempercayai terhadap fakta-fakta yang terdapat dalam teks, disertai dengan alasan-alasan yang kritis-analitis. Dengan demikian respons siswa terhadap teks yang dibacanya benar-benar murni, alami (natural) bertolak dari sikap siswa yang jernih sesuai dengan tingkat kematangan psikologis dan ketajaman intelektualnya. Prokreasi dalam tingkatan produksi dilakukan dalam bentuk lisan maupun tertulis. Pada tahap ini siswa dituntut mengungkapkan penilaiannya secara komprehensif terhadap teks yang dibacanya. Penilaian yang dilakukan meliputi penilaian kualitas tulisan, baik dari segi isi maupun gaya penulisannya berdasarkan kriteria yang dapat dipertanggungjawabkan. Siswa juga harus mampu menganalisis dan menilai apakah yang dibacanya itu bermanfaat atau tidak, memiliki kalaikan atau tidak apabila disampaikan kepada orang lain.

Bahan ajar yang dipilih dalam pembelajaran membaca kritis diusahakan dapat memberikan pengetahuan baru dan meningkatkan keterampilan membaca siswa. Berkaitan dengan keterampilan membaca kritis dalam pembelajaran, penting sekali diperhatikan mengenai bahan ajar yang digunakan. Bahan ajar yang digunakan untuk membaca kritis perlu memperhatikan aspek-aspek sebagai berikut: (1) mengandung isi yang dapat diperdebatkan, (2) memuat fakta yang dapat ditelusuri kebenarannya, (3) mengandung opini yang mudah dimengerti 

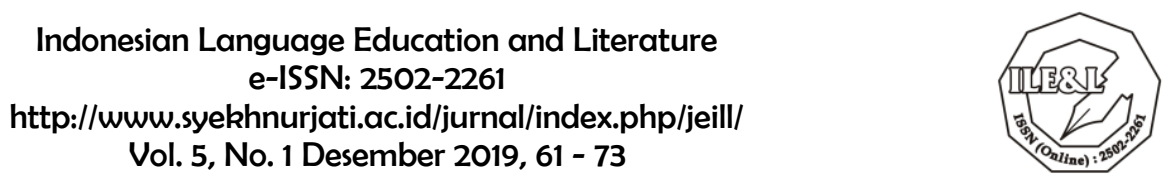

oleh siswa, (4) sistematika berpikir penulis yang diuraikan dalam teks jelas, sehingga siswa dapat menganalisis argumen dan simpulan, (5) ditulis oleh penulis yang memiliki latar belakang atau riwayat kepenulisan yang dapat ditelusuri, (6) sesuai dengan keadaan sosial dan budaya siswa, (7) mengandung isi yang dapat menambah pengetahuan baru bagi siswa. Mengacu pada beberapa kriteria tersebut maka bahan ajar yang cocok untuk pembelajaran membaca kritis adalah teks eksplanasi. Teks eksplanasi merupakan jenis teks baru yang ada pada pembelajaran bahasa Indonesia Kurikulum 2013. Teks eksplanasi merupakan jenis teks yang menjelaskan hubungan logis dari beberapa peristiwa.

Hasil penelitian ketiga menjelaskan tentang kendala-kendala yang dihadapi guru dan siswa dalam melaksanakan pembelajaran membaca kritis teks eksplanasi dengan model rekreasi-prokreasi. Kendala-kendala tersebut menyangkut kurang tersedianya alat pelajaran dan media pembelajaran, siswa kurang aktif dalam berdiskusi, guru belum mampu menjadi fasilitator pembelajaran membaca kritis secara baik, terbatasnya kemampuan berbahasa siswa, terutama dalam menyusun kalimat, memilih kata, dan menyusun gaya bahasa.

Pengajaran bahasa sebaiknya diniatkan sebagai pembangunan literasi kritis. Literasi kritis yang dimaksud mencakup sikap dan keterampilan yang ktitis dan analitis untuk memahami dan menginterpretasi teks-teks ujaran maupun teks tertulis. Pembelajaran bahasa Indonesia tidak sekadar mencapai keterampilan berbahasa Indonesia, tetapi mengarah pada peningkatan kemampuan berpikir kritis dan kreatif. Salah satu cara untuk meningkatkan kemampuan berpikir kritis dan kreatif yaitu melalui kegiatan membaca kritis. Untuk itu, sekolah perlu menyiapkan perangkat keras dan perangkat lunak dan fasilitas-fasilitas lain yang dibutuhkan guru untuk melaksanakan pembelajaran membaca kritis.

Sebuah keterampilan kemungkinan dibangun dari beberapa keterampilan yang lain, misalnya keterampilan menyimpulkan melibatkan keterampilan mengingat, membandingkan, mengidentifikasi hubungan. Kompleksitas sebuah keterampilan juga bergantung pada area isi (bidang kajiannya). Sebagai contoh, membuat ringkasan dapat dianggap keterampilan yang sederhana karena hanya menemukan ide pokok yang tersurat, tetapi membuat ringkasan juga melibatkan kombinasi keterampilan kompleks tingkat tinggi untuk menyeleksi dan 
mengurutkan informasi dari teks verbal yang padat dan grafik. Begitu juga dengan keterampilan membaca kritis, selain membutuhkan kemampuan menganalisis, mensintesis, menilai, juga memerlukan keterampilan berbahasa. Tanpa kemampuan berbahasa yang baik maka hasil analisis dan penilaian sekritis apa pun tidak akan bisa diekspresikan dengan baik. Untuk itu, pembelajaran membaca kritis harus diimbangi dengan penguatan keterampilan berbahasa siswa.

Proses membaca yang dilakukan siswa hanya sebatas mengingat belum menerapkan proses membaca kritis. Hal ini, secara tidak langsung memberikan dampak terhadap proses pembelajaran khususnya belajar bahasa dan sastra Indonesia. Oleh sebab itu, guru harus mampu menerapkan proses membaca kritis dengan menerapkan inovasi dalam pembelajaran, sehingga siswa lebih kritis dalam memahami, menganalisis, dan memberikan penilaian terhadap suatu permasalahan. Guru harus mendorong siswa mampu mengungkapkan kembali menurut pemahamannya dengan bahasa yang baik.

\section{SIMPULAN}

Berdasarkan analisis dapat disimpulkan bahwa pembelajaran membaca kritis belum terlaksana dengan baik. Hal ini disebabkan oleh aspek membaca kritis tidak berdiri sendiri sebagai sebuah KD, kekurangtepatan guru dalam memilih metode, materi, dan media pembelajaran dalam pembelajaran membaca kritis. Pembelajaran membaca kritis teks eksplanasi dengan model rekreasiprokreasi mampu menciptakan suasana pembelajaran baru yang menyenangkan bagi siswa, mendorong tumbuh kembangnya kemampuan berpikir kritis, berani mengemukakan pendapat, dan meningkatkan kemampuan berbahasa lainnya. Kendala yang dihadapi dalam pembelajaran membaca kritis teks eksplanasi, yaitu kurang tersedianya alat dan media pembelajaran, siswa kurang aktif dalam berdiskusi, guru belum mampu menjadi fasilitator pembelajaran membaca kritis secara baik, terbatasnya kemampuan berbahasa siswa, terutama dalam menyusun kalimat, memilih kata, dan menyusun gaya bahasa. 


\section{DAFTAR PUSTAKA}

Cahyono, B.E.H. (2017). Model Pembelajaran Cerita Pendek Berbasis Pengembangan Kreativitas. Surakarta: Djiwa Amarta.

Dalman. (2014). Keterampilan Membaca. Jakarta: Raja Grafindo Persada.

Faisal, S. (2003). "Pengumpulan dan Analisis Data dalam Penelitian Kualitatif". dalam Burhan Bungin (ed). Analisis Data Penelitian Kualitatif. Jakarta: Raja Grafindo Persada.

Hayati, N., Atmazaki, \& Abdurrahman. (2015). Hubungan Keterampilan Membaca Kritis dengan Keterampilan Menulis Artikel Populer Berdasarkan Gaya Belajar Siswa Kelas XI SMA Negeri 5 Padang. Jurnal Bahasa, Sastra dan Pembelajaran, 2(1), 38 - 48.

Hudaa, S. (2018). Efektivitas Pembelajaran Bahasa Indonesia Menggunakan Pendekatan Student Active Learning di Jurusan Manajemen Fakultas Ekonomi dan Bisnis UIN Syarif Hidayatullah Jakarta. BAHASTRA, 38(1). DOI: doi.org/10.26555/bahastra.

Jamaris, M. (2005). Perkembangan dan Perkembangan Anak Usia Taman Kanakkanak. Jakarta: Program Studi PAUD PPS UNJ.

Livne, N.L. (2008). Enhanching Mathematical Creativity through Multiple Solution to Open-Ended Problems Online. http://www.iste.org/ Content./ NavigationMenu/ Research/NECC_Research_Paper_Archives/ NECC2008/ Livne.pdf. Diunduh tanggal 14 November 2017.

McGregor, D. (2007). Developing Thinking Developing Learning. Poland: Open University Press.

Miles, M.B. \& Huberman, A. M. (1992). Analisis Data Kualitatif (terj. Tjetjep Rohendi Rohidi). Jakarta: Universitas Indonesia.

Muhyidin, A. (2018). "Minat Baca dan Penguasaan Kosakata Serapan Asing." Indonesian Language Education and Literature. 3(2). 143-156. doi 10.24235/ileal.v3i2.1835.

Suharman. (1998). "Pengaruh Pelatihan Imajeri dan Penalaran terhadap Kreativitas menurut Prespektif Perbedaan Individu”. Disertasi.Yogyakarta: Universitas Gadjah Mada.

Sutopo, H.B. (2002). Metodologi Penelitian Kualitatif. Surakarta: Sebelas Maret University Press. 